\title{
Sustainability Index for Water Resources Planning and Management
}

\author{
S. Sandoval-Solis ${ }^{1}$; D. C. McKinney, M.ASCE ${ }^{2}$; and D. P. Loucks, M.ASCE ${ }^{3}$
}

\begin{abstract}
This paper presents a water resources sustainability index that makes it possible to evaluate and compare different water management policies with respect to their sustainability. The sustainability index identifies policies that preserve or improve the desired water management characteristics of the basin in the future. This index is based on a previous sustainability index with improvements in its structure, scale, and content to make it more flexible and adjustable to the requirements of each water user, type of use, and basin. The Rio Grande transboundary basin is used as a case study demonstrating the use of the index. Tailor-made sustainability indexes are defined for water users in Mexico, the United States, the environment, and for meeting system requirements (international treaty obligations). Group sustainability indexes are calculated to summarize the results for groups of water users of each country, the environment, and the basin as a whole. Sustainability indexes by subbasins are calculated to identify areas of potential improvement and regions at risk. DOI: 10.1061/ (ASCE)WR.1943-5452.0000134. (C) 2011 American Society of Civil Engineers.
\end{abstract}

CE Database subject headings: Sustainable development; Water resources; Rio Grande; Water management.

Author keywords: Sustainability index; Sustainable policies; Adaptive capacity; Water resources; Rio Grande.

\section{Introduction}

It has been 30 years since the concept of sustainable development was introduced for the first time by the World Conservation Strategy [International Union for Conservation of Nature (IUCN) 1980]. Sustainable development balances the exploitation of natural resources, technology development, and institutional change to enhance the potential to meet human needs and aspirations, now and in the future [World Commission on Environment and Development (WCED) 1987]. To achieve sustainability, all the components in the system must be also in balance. Loucks (1997) defined sustainable water resources systems as "those systems designed and managed to contribute fully to the objectives of society, now and in the future, while maintaining their ecological, environmental and hydrological integrity." Although this concept is still valid, water management policies that promote sustainable water resources systems are becoming more difficult to identify because of environmental considerations, water scarcity, and climate change.

Recently, strong emphasis has been placed on the adaptive capacity of water resource systems, which refers to measures that reduce the vulnerability of systems to actual or expected future changes. Vulnerability is the magnitude of an adverse impact on a system. Thus, the objective is to look for policies that reduce the adverse impacts of actual and expected events, and to the extent possible, meet the water requirements for humans and the

${ }^{1}$ Dept. of Land, Air and Water Resources, Univ. of California, Davis, CA 95616-8627; formerly, Center for Research in Water Resources, Univ. of Texas, Austin, TX 78712. E-mail: samsandoval@ucdavis.edu

${ }^{2}$ Center for Research in Water Resources, Univ. of Texas, Austin, TX 78712 (corresponding author). E-mail: daene@aol.com

${ }^{3}$ School of Civil and Environmental Engineering, Cornell Univ., Ithaca, NY 14853. E-mail: loucks@cornell.edu

Note. This manuscript was submitted on March 27, 2010; approved on October 21, 2010; published online on October 26, 2010. Discussion period open until February 1, 2012; separate discussions must be submitted for individual papers. This paper is part of the Journal of Water Resources Planning and Management, Vol. 137, No. 5, September 1, 2011. CASCE, ISSN 0733-9496/2011/5-381-390/\$25.00. environment, now and in the future. To accomplish this goal, it is necessary to have performance measures or indexes that allow the evaluation and comparison of water resources systems under different scenarios. The objective of this paper is to present a water resources sustainability index that makes it possible to evaluate and compare alternative management policies for water resources systems.

The sustainability index (SI) summarizes the performance of alternative policies from the perspective of water users and the environment; it is also a measure of a system's adaptive capacity to reduce its vulnerability. If a proposed policy makes the system more sustainable, the index will show that the system will have a larger adaptive capacity. The index proposed here is a variation of the sustainability index developed by Loucks (1997) with improvements in its structure, scale, and content to make it more flexible and adjustable to the requirements of each basin. The SI is an integration of performance criteria that capture the essential and desired sustainable characteristics of the basin. The index facilitates comparison of policies when there are trade-offs among performance criteria.

First, the performance criteria parameters used in the SI are described. Second, the SI for individuals and water user groups is defined. Third, water management in the Rio Grande basin, used as a case study, is presented. Fourth, the SI for the current water management policy and three adaptation policies are defined for different groups of stakeholders in the Rio Grande basin. Finally, conclusions and recommendations are presented.

\section{Performance Criteria}

Performance criteria are used to evaluate water management policies and enable the comparison of alternative policies. Performance criteria can be simple averages, such as system storage, water supply, evaporation, municipal shortfalls (average deficits), and outflow of water from a system (Vigerstol 2002). Probabilitybased performance criteria include time-based (annual, monthly) 
and volumetric reliability [Texas Commission on Environmental Quality (TCEQ) 2007], and resilience (Hashimoto et al. 1982).

\section{Reliability}

Water demand reliability is the probability that the available water supply meets the water demand during the period of simulation (Klemes et al. 1981; Hashimoto et al. 1982). For each time period $t$, deficits $D_{t}^{i}$ are positive when the water demand $X_{\text {Target, } t}^{i}$ is more than the water supplied $X_{\text {Supplied }, t}^{i}$ for the $i$ th water user; if the water supplied is equal to water demand $\left(X_{\text {Supplied }, t}^{i}=X_{\text {Target }, t}^{i}\right)$, deficits are zero $\left(D_{t}^{i}=0\right)$ (Loucks 1997).

$$
D_{t}^{i}= \begin{cases}X_{\text {Target }, t}^{i}-X_{\text {Supplied }, t}^{i} & \text { if } X_{\text {Target }, t}^{i}>X_{\text {Supplied }, t}^{i} \\ 0 & \text { if } X_{\text {Target }}^{i}=X_{\text {Supplied }, t}^{i}\end{cases}
$$

Time-based reliability $\mathrm{Rel}^{i}$ is considered, which is the portion of time that the water demand is fully supplied, the number of times $D_{t}^{i}=0$, with respect to the number of time intervals considered (e.g., $n$ months or years) (McMahon et al. 2006):

$$
\operatorname{Rel}^{i}=\frac{\text { No. of times } D_{t}^{i}=0}{n}
$$

\section{Resilience}

Resilience is a system's capacity to adapt to changing conditions [World Health Organization (WHO) 2009]. Because climate conditions are no longer steady, resilience must be considered as a statistic that assesses the flexibility of water management policies to adapt to changing conditions. According to Hashimoto et al. (1982), resilience is the probability that a system recovers from a period of failure. Moy et al. (1986) used the maximum number of consecutive deficit periods prior to recovery as an alternative definition of resilience. Resilience $\operatorname{Res}^{i}$ is the probability that a successful period follows a failure period (the number of times $D_{t}^{i}=0$ follows $D_{t}^{i}>0$ ) for all failure periods (the number of times $D_{t}^{i}>0$ occurred). This statistic assesses the recovery of the system once it has failed:

$$
\operatorname{Res}^{i}=\frac{\text { No. of times } D_{t}^{i}=0 \text { follows } D_{t}^{i}>0}{\text { No. of times } D_{t}^{i}>0 \text { occurred }}
$$

\section{Vulnerability}

Vulnerability is the likely value of deficits, if they occur (Hashimoto et al. 1982). Essentially, vulnerability expresses the severity of failures. Vulnerability can be expressed as (1) the average failure (Loucks and van Beek 2005); (2) the average of maximum shortfalls over all continuous failure periods (Hashimoto et al. 1982; McMahon et al. 2006); and (3) the probability of exceeding a certain deficit threshold (Mendoza et al. 1997). This paper uses the first approach, the expected value of deficits, which is the sum of the deficits, $D_{t}^{i}$, divided by the deficit period, the number of times $D_{t}^{i}>0$ occurred. Dimensionless vulnerability is calculated by dividing the average annual deficit by the annual water demand, water demand ${ }^{i}$, for the $i$ th water user:

$$
\mathrm{Vul}^{i}=\frac{\left(\sum_{t=0}^{t=n} D_{t}^{i}\right) / \text { No. of times } D_{t}^{i}>0 \text { occurred }}{\text { Water demand }^{i}}
$$

\section{Standard Deviation}

The standard deviation of the water supply for the $i$ th water user in period $t$ is

$$
\sigma^{i}=\frac{\sqrt{\left[\sum_{t=1}^{t=n}\left(X_{\text {Supplied }, t}^{i}-\bar{X}_{\text {Supplied }}^{i}\right)^{2}\right] /(n-1)}}{\text { Water demand }{ }^{i}}
$$

where the average water supply $\bar{X}_{\text {Supplied }}^{i}$ is

$$
\bar{X}_{\text {Supplied }}^{i}=\frac{1}{n} \sum_{t=1}^{t=n} X_{\text {Supplied }, t}^{i}
$$

This performance criterion (Hirsch 1979; Cai et al. 2002) indicates the variability of the water supply when part or all of a user's water demand is not supplied from controlled facilities, such as unregulated rivers. A dimensionless standard deviation has been defined in Eq. (5) by dividing the volumetric standard deviation by the annual water demand, water demand ${ }^{i}$.

\section{Maximum Deficit}

The maximum deficit, if deficits occur, is the worst-case annual deficit, $\max \left(D_{\text {Annual }}^{i}\right)$, for the $i$ th water user (Moy et al. 1986). A dimensionless maximum deficit is calculated by dividing the maximum annual deficit by the annual water demand,

water demand ${ }^{i}$ :

$$
\operatorname{Max}_{\operatorname{def}}^{i}=\frac{\max \left(D_{\text {Annual }}^{i}\right)}{\text { Water demand }^{i}}
$$

\section{Sustainability Index}

Indexes represent aggregate measures of a combination of performance measures, or in other words, an index is a "synthesis of numerous factors into one given factor" (Sainz 1989). Several indexes have been developed for environmental processes, such as the environmental index (Milbrink 1983), environmental stresses index (Reiquam 1972), environmental sustainability index (Esty et al. 2005), the multiattributed environmental index (Hajkowicz 2006), and also some indexes specifically for water resources, such as the drought risk index (Zongxue et al. 1998), the Palmer drought severity index (Palmer 1965), water quality index (Brown et al. 1972), fairness (Lence et al. 1977), reversibility (Fanai and Burn 1997), and consensus (Simonovic 1998).

To quantify the sustainability of water resources systems, Loucks (1997) proposed the SI, with the objective to facilitate the evaluation and comparison of water management policies. The SI is a summary index that measures the sustainability of water resources systems; it can be used to estimate the sustainability for water users and to obtain the change in sustainability by comparing the index among several water policies proposed. Frequently, indexes are criticized because they are seen as a sum of disparate items (Hopkins 1991), and sometimes in practice, people in the water sector are reluctant to use indexes (Brown et al. 1972). The SI summarizes essential performance parameters of water management in a meaningful manner, rather than adding broad factors, and the SI has been used by the scientific community (Ray et al. 2010; McMahon et al. 2006; Loucks 1997).

\section{Sustainability by User}

Loucks (1997) proposed the following SI for the $i$ th water user:

$$
\mathrm{SI}^{i}=\operatorname{Rel}^{i} * \operatorname{Res}^{i} *\left(1-\mathrm{Vul}^{i}\right)
$$


The SI has the following properties: (1) its values vary from 0-1; (2) if one of the performance criteria is zero, the sustainability will be zero also; and (3) there is an implicit weighting because the index gives added weight to the criteria with the worst performance. The multiplicative form of the SI considers each criterion as essential and nonsubstitutable. Sagar and Najanm (1998) suggested this as the proper manner for integrating performance criteria. For instance, Reiquam (1972) used the multiplicative form for the environmental stresses index.

A variation of Loucks' SI is proposed here, with the index defined as a geometric average of $M$ performance criteria $\left(C_{m}^{i}\right)$ for the $i$ th water user:

$$
\mathrm{SI}^{i}=\left[\prod_{m=1}^{M} C_{m}^{i}\right]^{1 / M}
$$

For instance, if the performance criteria are $C_{1}^{i}=\mathrm{Rel}^{i}$, $C_{2}^{i}=\operatorname{Res}^{i}$, and $C_{3}^{i}=1-\mathrm{Vul}^{i}$, the SI for the $i$ th water user is

$$
\mathrm{SI}^{i}=\left[\operatorname{Rel}^{i} * \operatorname{Res}^{i} *\left(1-\operatorname{Vul}^{i}\right)\right]^{1 / 3}
$$

This index satisfies the properties of the SI defined by Loucks (1997), but, in addition, it has the following improvements:

Content-It allows the inclusion of other criteria of interest according to the necessities of each case. The SI is no longer a fixed performance criteria related to water quantity; performance criteria of water quality and environmental performance might be included in the SI. For instance, if the total dissolved solids (TDS) of the water delivered to a user must be below a permitted value, the reliability for TDS not exceeding the desired threshold can be calculated and included in the SI. The criteria $\left(C_{m}^{i}\right)$ included in Eq. (9) must have a scale from $0-1$, and desirable criteria values tend to 1 . Scaling and complements $1-C_{m}^{i}$ can be applied prior to including any performance criteria into Eq. (10).

Scaling - The use of the geometric average scales the values of the SI, generating numbers that can be more practical to interpret and communicate. If a certain water user has a reliability, resilience, and vulnerability of $50 \%$ for each performance criterion, then the SI calculated with the prior definition [Eq. (8)] and the proposed index [Eq. (9)] are $13 \%$ and $50 \%$, respectively. The scaling of the SI does not obscure poor performance; its only purpose is to scale the values and make the index more practical and intuitive. In addition, more than three parameters can be included in the SI; the product of several factors will result in small numbers, and without scaling, changes in the SI might be difficult to discern.

Flexibility-Several structures for the SI might be applied in the same basin for different groups of water users or types of use. For instance, SI for municipal or recreational water use may include different performance criteria than the SI for agriculture water use. Water quality and environmental performance criteria may be included for municipal and recreational water use, respectively, and the standard SI [Eq. (10)] might be appropriate for agriculture use. Sustainability does not mean the same thing for all water users, and the proposed index allows it to be adjusted to suit the user or use of water.

The improvements to the SI are not merely mathematical. The updated SI is a holistic approach to define the sustainability for each group of water user. The structure of the index incorporates tailor-made parameters that for some water users may be crucial to their water management; the scaling of the index allows a more intuitive result; and the flexibility to use different SI structures in the same system allows the meaningful discrimination of performance parameters for specific groups of water users.

\section{Sustainability by Group}

To compare groups of water users, the sustainability by group (SG) was defined as a weighted average of sustainability indexes (Loucks 1997). The SG is used to calculate the sustainability for a group $k$ with $i$ th to $j$ th water users belonging to this group:

$$
\mathrm{SG}^{k}=\sum_{i=1 \in k}^{i=j \in k} W^{i} * \mathrm{SI}^{i}
$$

where $W^{i}=$ relative weight for the $i$ th water user, ranging from $0-1$ and summing to one. If the SI of each user is weighted by its annual water demand, the SG for the $k$ th group is expressed as

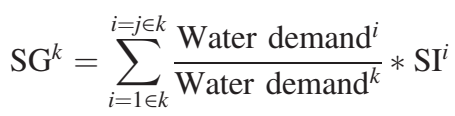

where

$$
\text { Water demand }{ }^{k}=\sum_{i=1 \in k}^{i=j \in k} \text { Water demand }{ }^{i}
$$

The relative importance of each variable is reflected in the weights. There are many weighting options, such as (1) an arithmetic average or equal-attribute-based weighting system (Slottje 1991; Reiquam 1972); (2) explicit weights obtained through (a) utility theory analysis (Loucks et al. 1997; Von Neumann and Morgenstern 1974), principal components analysis, or hedonic model according to regression coefficients (Slottje 1991); or (b) weights defined by consultations with experts (Gwartney et al. 1996), decision makers (Vigerstol 2002), or researcher expertise (Giorgi and Mearns 2002). Weights of Eq. (12) obtained through the annual water demand are used in this paper, considering that (1) the necessities of the water users and the environment can be expressed in the water demand value; (2) in interviews, authorities and water users agreed with this formulation; and (3) other performance criteria of interest are functions of water demand value, and can be scaled (normalized) using it, i.e., vulnerability, maximum deficit and standard deviation. The authors considered that the water necessities for water users and the environment are expressed in their water demand. However, there are limitations when water demands have not yet been estimated, e.g., for the environment, or when the water demand provided by the authorities underestimates the water necessities for water users and the environment.

\section{Rio Grande Basin}

The Rio Grande basin is a transboundary basin between the United States and Mexico [Fig. 1(a)]. Because of its geographical position, it is one of the most stressed basins in the world [World Wildlife Fund (WWF) 2007], not only because of the increase in water demand as a result of population and industry growth, but also because of the natural water scarcity in the region. Extended periods of drought ( $>10$ years), coupled with overallocation of water rights, low efficiency in irrigation systems, and international agreements, make the Rio Grande basin a highly complex water resources system.

\section{Water Management Principles for the Rio Grande Basin}

The Rio Grande basin is used to exemplify the proposed SI. The middle and lower part of the basin is analyzed from Elephant Butte dam in New Mexico to the mouth at the Gulf of Mexico 


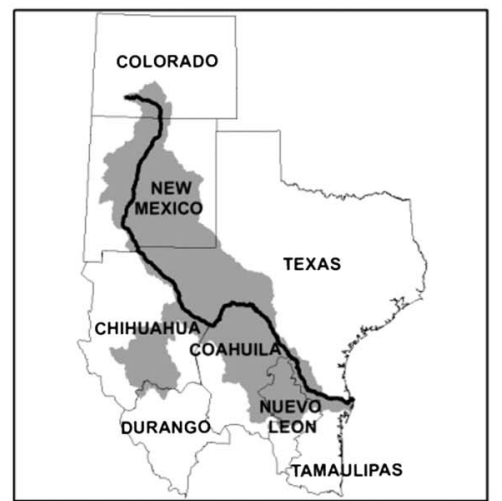

(a)

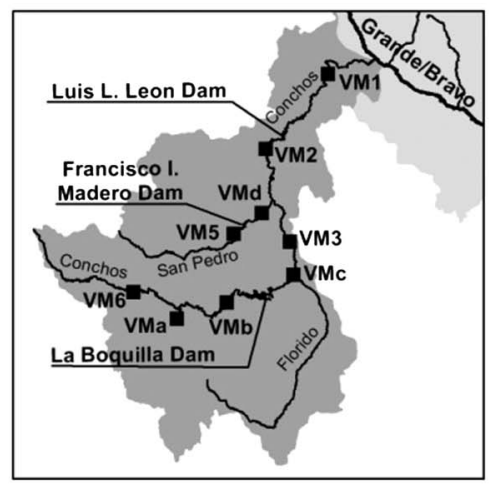

(c)

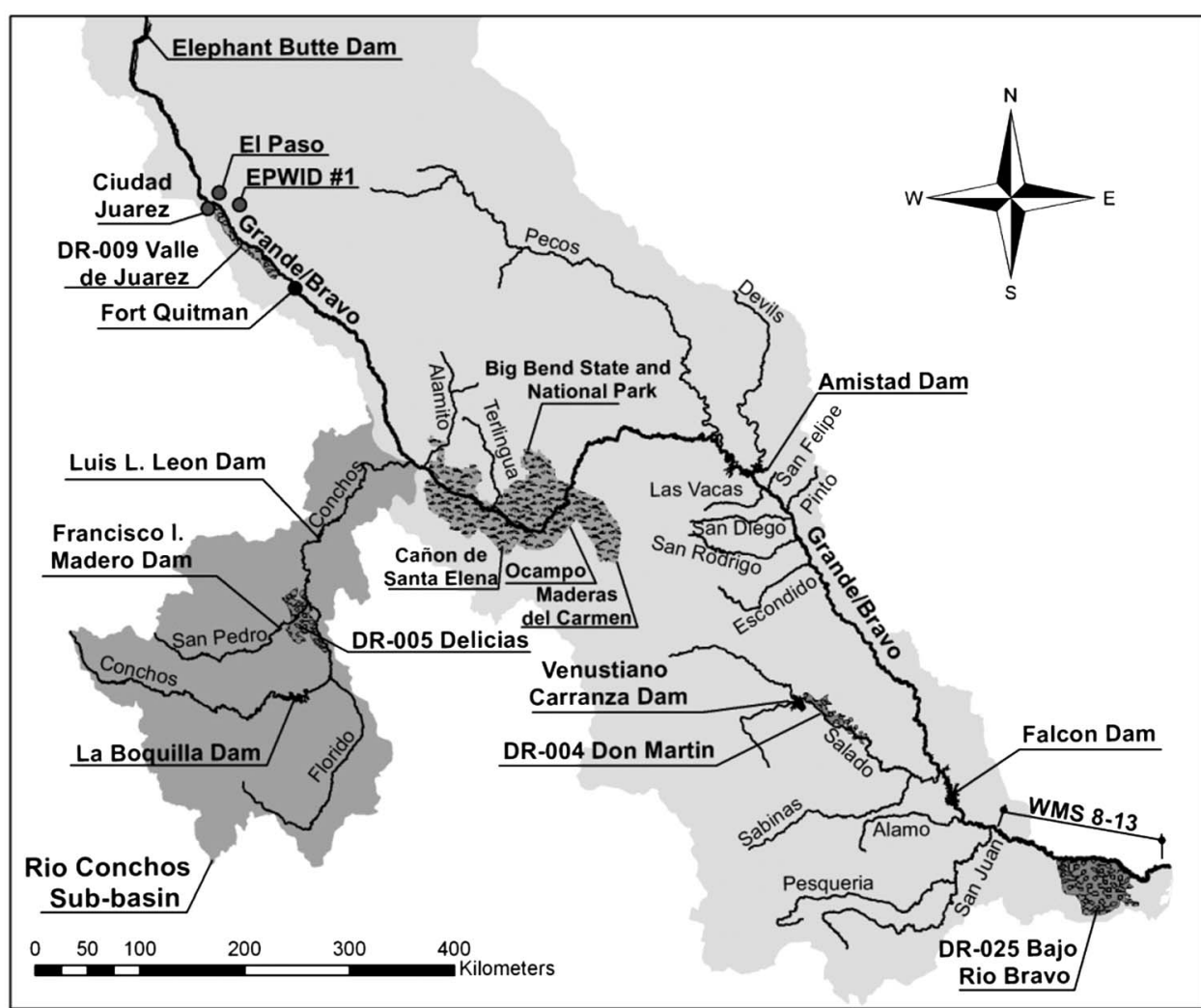

(b)

Fig. 1. (a) Rio Grande basin; (b) hydrography of Rio Grande basin; (c) environmental control points

[Fig. 1(b)]. Water management of the basin results from four aspects: (1) international agreements; (2) Mexican water policies; (3) U.S. water policies; and (4) the environment.

\section{International Agreements: Treaty of 1944}

The 1944 treaty between United States and Mexico specifies the water allocation for both countries [International Boundary and Water Commission (IBWC) 1944] with a primary division of six tributaries originating in Mexico as one-third to the United States and two-thirds to Mexico. The third shall not be less than 431.721 million $\mathrm{m}^{3}$ /year as an average over cycles of five consecutive years. Two international dams (Amistad and Falcon) are used to store and manage the water for both countries, and each country has its own storage account in each reservoir. The treaty cycles can expire in less than five years if the account of U.S. storage in both dams is filled with water. At the end of a 5-year cycle, the IBWC evaluates the Mexican delivery of water to the U.S. and determines if the treaty obligations have been met. If there is a deficit in the treaty delivery, it must be paid in the following cycle (IBWC 1944).

The sustainability index proposed for the treaty obligations is

$$
\mathrm{SI}^{\text {Treaty }}=\left[\operatorname{Rel}^{\text {Treaty }} * \operatorname{Res}^{\text {Treaty }} *\left(1-\mathrm{Vul}^{\text {Treaty }}\right) *\left(1-\sigma^{\text {Treaty }}\right)\right]^{1 / 4}
$$

Four out of the six Mexican tributaries delivering water to the treaty are unregulated rivers (Arroyo Las Vacas, San Diego, San Rodrigo, and Escondido). In addition, there is no defined policy in the other two regulated rivers (Rio Conchos and Salado) to deliver water to meet treaty obligations. In practice, only the gains of the reach between the most downstream reservoir in each tributary and the Rio Grande confluence are left in the river to meet the treaty obligations. Sporadically, reservoir spills during the hurricane season contribute to the delivery of treaty obligations. Because of the uncontrolled nature of the treaty deliveries, the standard deviation criterion is included in the SI to assess treaty obligations and help identify adaptation policies that reduce the variability of deliveries, providing a more steady delivery of treaty water by increasing low flows during drought periods and reducing spills during wet periods. The standard deviation for the treaty obligations is calculated from the annual deliveries of the six Mexican tributaries.

\section{Mexican Water Policy}

Mexican water demands are characterized by use [Comisión Nacional del Agua (CONAGUA) 2004a]. For this research, municipal, domestic, and agricultural water users are considered, accounting for the $99.2 \%$ of the total Mexican water demand (CONAGUA 2004b). Municipal and domestic users have the highest priority, and two times their annual water demand must be stored in the reservoirs. Water allocations to agricultural users are not guaranteed, and their allocations depend on the available storage in the respective dams that supply them. Each October, CONAGUA (the water authority in Mexico) determines the available reservoir storage after deducting municipal allocations, evaporation, and operation losses (Collado 2002). Then, a negotiation between CONAGUA and the irrigation districts sets the agricultural water allocation for the coming water year.

The sustainability index proposed for Mexican water users is

$$
\mathrm{SI}^{\mathrm{MX} i}=\left[\operatorname{Rel}^{\mathrm{MX} i} * \operatorname{Res}^{\mathrm{MX} i} *\left(1-\mathrm{Vul}^{\mathrm{MX} i}\right) *\left(1-\operatorname{Max}_{\operatorname{def}}{ }^{\mathrm{MX} i}\right)\right]^{1 / 4}
$$

The Rio Grande is a naturally water-scarce basin; extended and severe periods of drought have occurred in the basin. During the 
latest drought (1994-2003), Mexico was not able to deliver the the 1944 treaty: Cycle 25 (1992-1997) and Cycle 26 (1997-2002). To cover these deficits, extraordinary measures were taken by the authorities, such as stopping the supply for some Mexican irrigations districts and transferring Mexican storage in the international reservoirs to the United States These decisions severely affected Mexican agriculture water users in the basin, almost extinguishing this activity in the lower part of the basin. Because of this, the maximum deficit criterion is included in the SI for Mexican water users.

\section{U.S. Water Policy}

The Texas Rio Grande water master program, represented by the TCEQ (the water authority in Texas). regulates the U.S. water diversion from the Amistad reservoir to the Gulf of Mexico (TCEQ 2005) based on to the U.S. storage provided by the IBWC. Each user has an account, and water is allocated (TCEQ 2006) based on the water use (irrigation, municipal, mining, industrial, and other) and the type of water right (Type A or B). Municipal and industrial users have the highest priority, and they are guaranteed an amount for each year. Allocations to the other users are not guaranteed and depend on the water remaining in their accounts.

The sustainability index proposed for U.S. water users is

$$
\mathrm{SI}^{\mathrm{US} i}=\left[\operatorname{Rel}^{\mathrm{US} i} * \operatorname{Res}^{\mathrm{US} i} *\left(1-\mathrm{Vul}^{\mathrm{US} i}\right) *\left(1-\mathrm{Max} \mathrm{def}^{\mathrm{US} i}\right)\right]^{1 / 4}
$$

Similar to Mexico, agricultural water users in the United States suffered shortages during the last drought, and so the maximum deficit criterion is also included in the SI for U.S. water uisers. treaty water to the United States in two consecutive cycles of

$$
\mathrm{SI}^{\mathrm{Env} i}=\left[\operatorname{Rel}^{\mathrm{Env} i} * \operatorname{Res}^{\mathrm{Env} i} *\left(1-\mathrm{Vul}^{\mathrm{Env} i}\right) *\left(1-\operatorname{Max}_{\operatorname{def}}{ }^{\mathrm{Env} i}\right)\right]^{1 / 4}
$$

\section{Simulation Model of the Rio Grande Basin}

To illustrate the use of the new SI, several scenarios of water management in the Rio Grande basin are evaluated. Water resource allocation in the Rio Grande basin has been simulated using the Water Evaluation and Planning System (WEAP) software (Danner et al. 2006). The allocation logic represented in the model follows the allocation of water for Mexico (CONAGUA 2004a), Texas (TCEQ 2006), and the international allocation of water established in the Convention of 1906 (IBWC 1906) and the treaty of 1944 (IBWC 1944). Data for naturalized flows, conveyance losses, reservoir capacities, and evaporation, among other variables, were provided by CONAGUA, TCEQ, and the IBWC (Danner et al. 2006). For the United States, $100 \%$ water demand is taken as the full allocation water right established by the TCEQ in the Water Availability program (TCEQ 2006). For Mexico, 100\% demand is taken as the volume declared by CONAGUA in 2004 (CONAGUA 2004b). Table 1 shows the water demands for each country. Monthly use coefficients are used to account for the seasonal variability for each demand. The period of analysis for the modeling is 60 years, using as input the naturalized streamflows from Qctober 1940 to Septembêr 2000. The Rio Grande model has been calibrated and yalidated using a 24-year period (1976-2000) over which both international reservoirs (Amistad and Falcon) were in existence; in addition, the historic records of water diversions were available for this period. The simulation process considered the repetition of the 60-year hydrologic period with the recent infrastructure and demands in the basin.

\section{Environment}

Environmental flows have not been considered an integral part of water management in the Rio Grande. Important environmental habitats, such as the Big Bend State and National Park in the United States, the northern Chihuahuan desert, Maderas del Carmen, Ocampo, and Cañon de Santa Elena natural reserves in Mexico, are ecologically threatened because of the lack of environmental water management policies. Historically, the basin has been manipulated in an exclusive human water resource management mode (Enriquez-Coyro 1976) without consideration for the environmental needs of the native ecosystems.

Several efforts have been undertaken to determine environmental flows needed in the basin (Sandoval-Solis and McKinney 2009). As part of an environmental flow assessment for the Rio Conchos, environmental flows were estimated at nine locations [Fig. 1(c)] (WWF 2006). A monthly variation for two conditions, maintenance or drought, was determined for each location. These flows were used to evaluate the performance of the environmental requirements. The sustainability index proposed for the environmental flows is

\section{Sustainability Index Use}

In complex, stressed, and shared water resources systems, such as the Rio Grande, it can be difficult to identify policies that improve water management. This section illustrates how the SI and SG can help identify which policies improve water management, for whom, where, and by how much. The SI and SG are comprehensive tools integrating multiple performance measures that facilitate the evaluation and comparison of different water management policies.

\section{By Water User}

To demonstrate the use of the proposed SI, two scenarios are compared systematically: a baseline scenario that represents current water management policies in the basin and an alternative scenario. The alternative scenarios represent policies that improve the efficiency of the system through water conservation measures, policies whose objectives are to reduce the use and/or consumption of water. In this section, alternative scenarios are analyzed in which

Table 1. Water Demands Considered in the Rio Grande WEAP Model

\begin{tabular}{lcccr}
\hline Water use & Mexico number of demands & Mexico demand (million m $\mathrm{m}^{3} /$ year) & U.S. number of demands & U.S. demand $\left(\mathrm{million} \mathrm{m}^{3} /\right.$ year) \\
\hline Municipal & 21 & 731 & 23 & $283^{\mathrm{a}}$ \\
Irrigation & 39 & 3,881 & 53 & $3,034^{\mathrm{a}}$ \\
Other & 1 & 47 & 20 & $11^{\text {a }}$ \\
Groundwater & 35 & 1,852 & 21 & $2,840^{\mathrm{b}}$ \\
Total & 96 & 6,511 & 120 & 6,168 \\
\hline
\end{tabular}

${ }^{\mathrm{a}}$ Full allocation demand for U.S. water demands. The current allocation is $70 \%$ of the full allocation.

${ }^{\mathrm{b}}$ This value represents an upper bound on aquifer withdrawal by these water demands. 
water demand is reduced below the baseline demand because of water conservation measures.

In the first alternative, Scenario A, water conservation measures are implemented in irrigation district 005 Delicias (DR-005), the biggest water user on the Mexican side with a demand of 942 million $\mathrm{m}^{3}$ /year. In Scenario A, the water demand is progressively reduced from $100 \%$ to $20 \%$ relative to the baseline scenario demand. Fig. 2 shows the results for DR-005 according to Eq. (15). Results show that as demand is reduced, (1) reliability increases; (2) vulnerability decreases; (3) resilience increases; (4) maximum deficit does not decrease; and (5) SI increases after a reduction to $70 \%$.

Are there any benefits in Scenario A? If so, are they immediate when the water demand is reduced or are they delayed? By how much? The performance criteria do not allow provide answers to these questions, but the SI does. For instance, for a 50\% reduction in DR-005 water demand, results of reliability, resilience, vulnerability, maximum deficit, and SI are $83 \%, 40 \%, 51 \%, 98 \%$, and $22 \%$, respectively. In contrast, for a $40 \%$ reduction in DR-005 water demand, results for the same performance criteria are $78 \%$, $23 \%, 45 \%, 96 \%$, and $24 \%$, respectively. Using the performance criteria it is difficult to discern if the $10 \%$ water demand reduction improved the water management; however, the SI shows an increase of $2 \%$. In addition, the water supply for DR-005 is not sustainable; one of the characteristics required for its sustainability [Eq. (15)] is a reduction in the maximum deficit, and in both scenarios it is almost $100 \%$. Although the reliability, resilience, and vulnerability improve, the demand reduction proposed in Scenario A does not solve the problem of high maximum deficit. In Scenario A, there is almost no improvement until the demand is reduced to $70 \%$; after this point, the water supply starts improving.

Two water conservation measures have already been implemented in the Rio Grande basin, specifically in DR-005: (1) the permanent buy-back of water rights through the Mexican Programa de Adquisicion de Derechos de Uso del Agua (PADUA) program [Secretaria de Agricultura, Ganadería, Desarrollo Rural, Pesca y Alimentación (SAGARPA) 2003]; and (2) improvements in the infrastructure to reduce conveyance losses and increase application efficiency through the 1944 treaty, Minute 309 (IBWC 2003). The result of both programs has been a savings of 366 million $^{3}$ /year (39\%): 10\% from PADUA and 29\% from Minute 309. Even though water demand has been reduced to $61 \%$ ( 575 million $\mathrm{m}^{3} /$ year); the maximum deficit problem is not solved. The risk of experiencing a high deficit (Max def $=99 \%$ ) is still imminent; this risk may leave
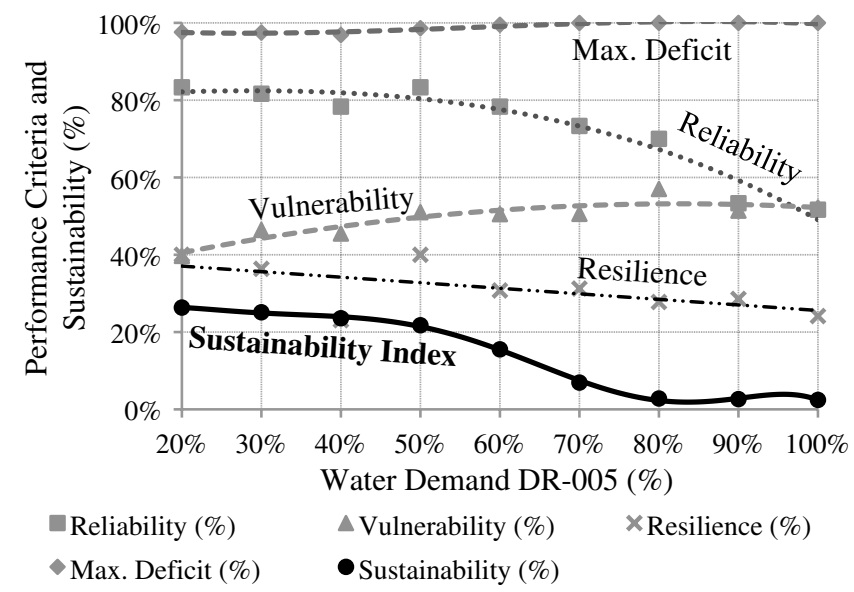

Fig. 2. Performance criteria and sustainability index values for DR005, Scenario A farmers without any income for at least 1 year. Adaptive policies that promote conjunctive use of surface and groundwater, such as the groundwater banking proposed by Sandoval-Solis et al. (2011), may reduce the risk of high deficits in DR-005.

Because there is no policy to allocate water to the environment, a hypothetical case in which the water saved in Scenario A is used to meet the environmental needs for the Rio Conchos subbasin is considered. For purposes of brevity, only the results for control point VMc Camargo are presented because this point has the worst performance in the baseline scenario. Fig. 3 shows the results according to Eq. (17). Results show that as water demand is reduced, (1) reliability and resilience increase; (2) vulnerability and the maximum deficit decrease; and (3) environmental sustainability for this control point improves significantly.

In Scenario A, when the water demand of DR-005 is reduced from $100 \%$ to $90 \%$ and the water savings are used for environmental purposes, the SI for the environment grows $33 \%$, from $24 \%$ to $57 \%$. The SI becomes steady at $60 \%$, meaning that Scenario A will be effective up to a $40 \%$ reduction in DR-005 demand, after this, no environmental benefits will be gained with this policy, and other adaptive policies should be used to further improve the environmental conditions. Under the baseline scenario, low reliability and resilience and high vulnerability and maximum deficit are expected for the environment ( $100 \%$ demand); thus, under the current policies, environmental sustainability is threatened.

Scenario B evaluates the water demand reduction of the user "Water Master Sections 8-13 Agriculture A" in Texas (WMS), the largest water user group on the U.S. side with a demand of 1,801 million $\mathrm{m}^{3} /$ year. In Scenario B, WMS demand is reduced progressively from $100 \%$ to $40 \%$. Fig. 4 shows the results according to Eq. (16). As water demand is reduced, (1) reliability increases; (2) resilience does not change until demand reaches a $50 \%$ reduction, after this point it increases quickly; (3) vulnerability and the maximum deficit decrease; and (4) sustainability improves. The SI shows that Scenario B is beneficial for WMS.

During the most recent drought (1994-2004), the water supply for the United States was compromised. The first three years of the drought (1994-1996), the water supply for WMS was $78 \%$ $\left(1,400\right.$ million $\mathrm{m}^{3} /$ year $)$ on average; for the rest of the drought (1997-2004), the water supply was $53 \%$ (950 million $\mathrm{m}^{3} /$ year) on average of the full allocation demand. This uncertainty in the water supply provoked the Texas legislature to order a study (Brandes 2004) that defined the water availability and the water use limits and vulnerabilities of the system. As a result, the current

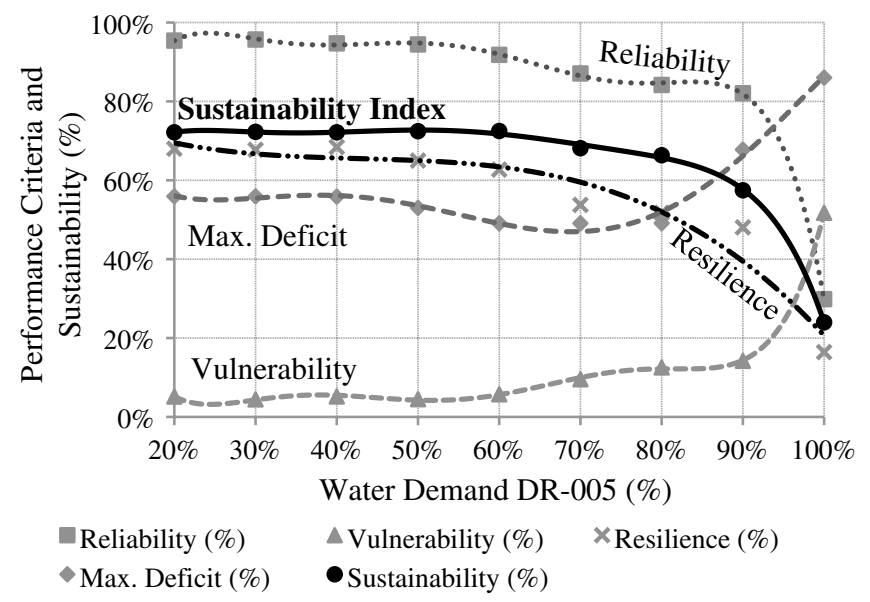

Fig. 3. Performance criteria and sustainability index values for the environmental control point VMc Camargo, Scenario A 


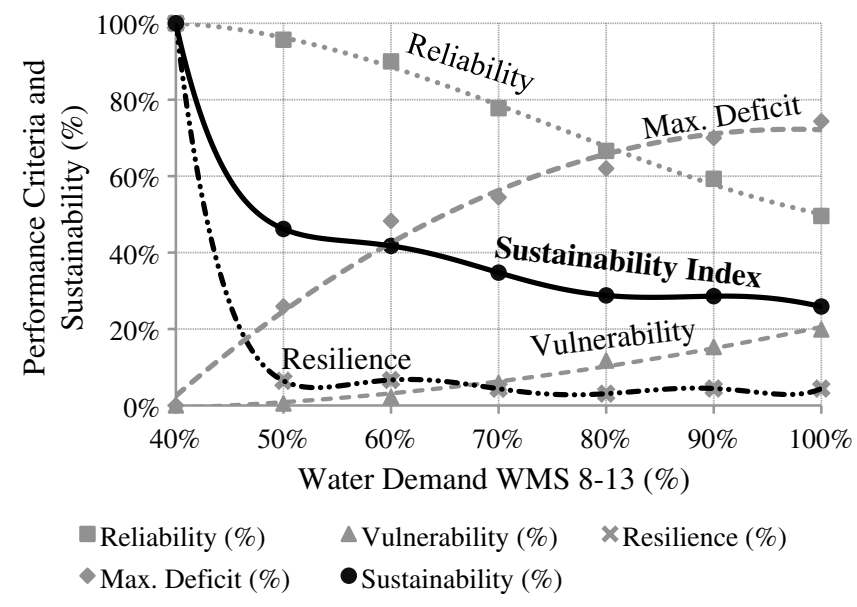

Fig. 4. Performance criteria and sustainability index values for WMS, Scenario B

allocation for U.S. water users other than municipal, domestic, and industrial was set at $70 \%$ of the full allocation demand (TCEQ 2007), and this has been further reduced to $62 \%$ (personal communication, C. Rubenstein, commissioner of TCEQ, October 2009). These decisions can be quantified by the SI: for $70 \%$ and $62 \%$ of the full demand, the SIs are $34 \%$ and $40 \%$, respectively. Thus, reducing the water allocation from $70 \%$ to $62 \%$ represents a $6 \%$ benefit in the water allocation for WMS.

In stressed basins such as the Rio Grande, adjustments in water management policy represent changes in the water allocation for stakeholders. The next example analyzes the effects of Scenario $\mathrm{B}$ on the treaty obligations. Fig. 5 shows the results for the treaty obligations according to Eq. (14). Reducing the WMS demand will result in (1) no change in the severity of the deficits (vulnerability) and in the variability of the deliveries (standard deviation); (2) an increase in the time the treaty obligations, will be met (reliability); and (3) an increase in the recovery of the system (resilience). The SI shows that the treaty obligations will benefit as a result of Scenario B.

The 1944 treaty specifies that Mexico must deliver to the United States a specified amount of water (2,159 million $\left.\mathrm{m}^{3}\right)$ during a 5 -year cycle; however, the cycles may expire earlier (less than 5 years) if the U.S. storage capacity in both international reservoirs

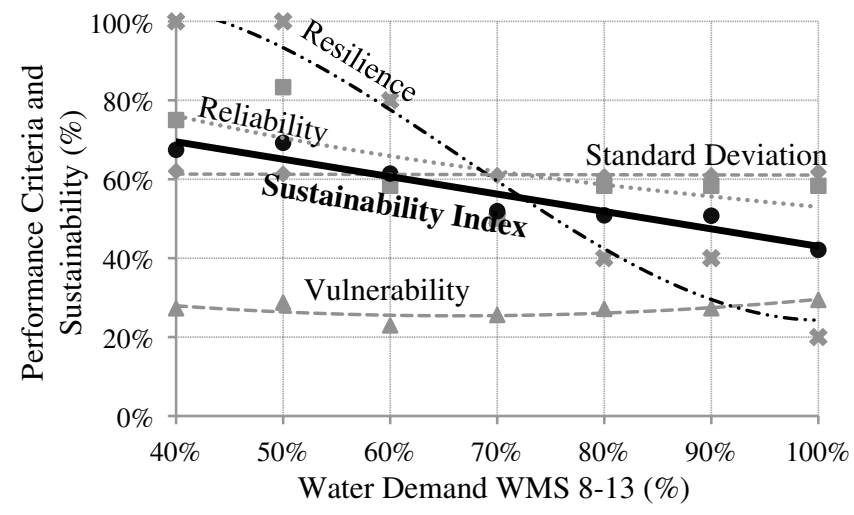

$$
\begin{array}{ll}
- \text { Reliability }(\%) & \Delta \text { Vulnerability }(\%) \\
\text { - Std. Deviation }(\%) & \bullet \text { Sustainability }(\%)
\end{array}
$$

Fig. 5. Performance criteria and sustainability index values for treaty obligations, Scenario B is filled. In Scenario B, the WMS demand is progressively reduced; therefore, less water is called for from the reservoirs, and as a result, the U.S. storage capacity in the international reservoirs is filled more frequently. Thus, the period of time the treaty obligations are met (reliability) is greater than the baseline scenario, and if a deficit happens, the system recovers faster because it is more likely that the deficit can be made up with delivery from the six tributaries or by filling the U.S. storage capacity. The SI shows that the treaty obligation improves under Scenario B. These results are important because they show that fulfilling the treaty obligations is not only a function of the water delivered by Mexico, but also of the water demand in the U.S.

\section{Sustainability by Group}

Each water user has a unique SI that depends on the structure defined for the specific water management group to which it belongs (United States, Mexico, environment, or treaty obligations). Because there are thousands of water users in the basin, and thus the same number of SIs, the SG, shown in Eq. (12), is used to further summarize the results. Through this method it is possible to (1) evaluate each water user according to required performance criteria defined for the management group to which it belongs; (2) summarize its performance by using the SI; and (3) summarize the performance of groups of water users by using the SG.

Table 2 shows the SG for five water user groups: (1) in the United States; (2) in Mexico with treaty obligations; (3) the environment in the Rio Conchos; (4) treaty obligations; and (5) all water users in the Rio Grande basin (including the environment and treaty obligations). Two scenarios are compared, the baseline scenario and Scenario C, which is a combination of Scenarios A and B. Scenario C considers the water demand for WMS at $62 \%$ of the full allocation (current policy), for DR-005 at $61 \%$ of the full allocation (demand after buy-backs and water conservation measures), and that the water savings in DR-005 are used for environmental flows.

Because of the reduction in the WMS water demand, the sustainability of the treaty obligations and the U.S. group increased by $19 \%$ and $11 \%$, respectively. Similarly, the sustainability for Mexico and the environment increased $16 \%$ and $8 \%$, respectively, because of the reduction in the water demand of DR-005 and the delivery of the saved water to the environment. Overall, the sustainability for the Rio Grande increased $15 \%$ with the adaptive strategies proposed in Scenario C.

In addition, water users have been grouped according to their location in the basin, using Eq. (12), to identify stressed water resource areas. Fig. 6 shows the SG of the baseline scenario for 12 geographic areas, five in the United States and seven in Mexico. For the United States, the Forgotten River (US-1), Pecos (US-2), and the lower Rio Grande valley (US-5) subbasins are the areas with the lowest sustainability. For Mexico, the Forgotten River (MX-1), Rio Conchos (MX-2), and Bajo Rio Bravo (MX-7) subbasins are the areas with the lowest sustainability.

Table 2. Sustainability by Group, Baseline, and Scenario C

\begin{tabular}{lccc}
\hline & \multicolumn{3}{c}{ Sustainability } \\
\cline { 2 - 4 } Group & Baseline $(\%)$ & Scenario C (\%) & $\Delta(\%)$ \\
\hline United States & 30 & 41 & +11 \\
Mexico & 33 & 49 & +16 \\
Treaty obligations & 51 & 70 & +19 \\
Environment & 62 & 70 & +8 \\
Rio Grande & 32 & 47 & +15 \\
\hline
\end{tabular}




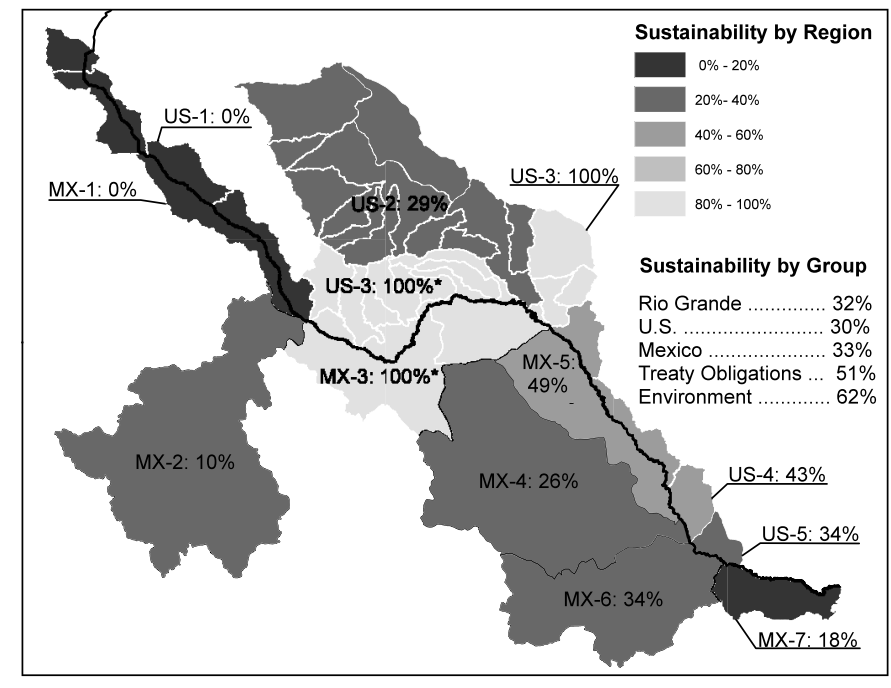

Fig. 6. Sustainability by region, baseline scenario

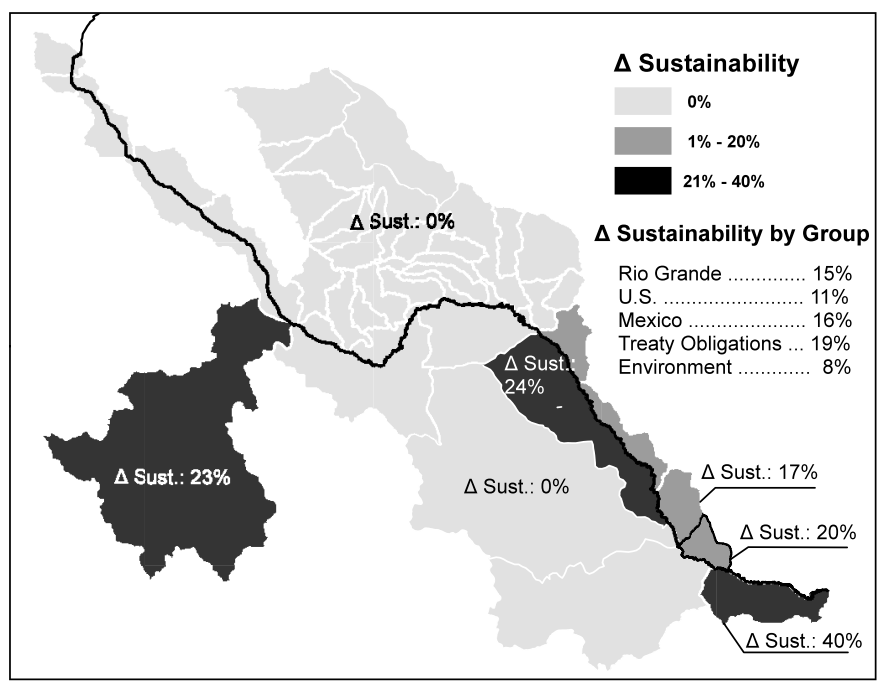

Fig. 7. Change in the sustainability index by subbasin
Along the border, three areas are of particular interest because of their complex water management: the Forgotten River (US-1/ MX-1), the Big Bend area (US-3/MX-3), and the lower Rio Grande valley (US-5/MX-7). The Forgotten River subbasin is the most stressed area in the basin. The growing water demand for municipal and industrial use in El Paso-Ciudad Juarez plus the agricultural use of El Paso Water Irrigation District \#1 (EPWID \#1) and DR-009 Valle de Juarez have exhausted the water resources in the area; the water demands are larger than the natural availability of water in this area. These conditions are indicated in the results with a sustainability of $0 \%$. For Mexican demands in this reach, the reliability is $0 \%$, meaning that during the simulation period there was never enough water to meet their water demand; demonstrating the overallocation of water rights. For U.S. demands in this reach, in at least 1 year they experienced a deficit of $100 \%$, so the maximum deficit criterion (1-Max def) was never met, demonstrating the stress of the system. After the Forgotten River, the lower Rio Grande valley is the most stressed area in the basin; water supply in this region depends on the water use in the whole basin. Water management in the tributaries consumes the water that is produced before it reaches the Rio Grande main stream. The water supply of the lower Rio Grande valley depends on the storage of the international reservoirs, which depend on the water from the tributaries. During drought periods, almost no water flows to the Rio Grande from the tributaries, storage in both international reservoirs is greatly decreased, and the water supply for this area is threatened. The SIs for MX-7 and US-5 are $18 \%$ and 34\%, respectively. The Big Bend region is another stressed area. Even though the sustainability is $100 \%$, this calculation does not consider the environmental needs for this region; the environmental flows for the Big Bend have not been defined yet. This result exemplifies a limitation of the SI and SG: when the water demand has not been calculated, e.g., for environmental flows in the Big Bend reach where water demands for other purposes are low, it is not possible to estimate the SI, and as a result, the SG does not consider this water demand. In addition, most of the water in the Big Bend area comes from the Rio Conchos ( $75 \%$ on average) and is managed by CONAGUA without a defined policy to deliver water from the Rio Conchos to the Rio Grande. An international team has been working to define the environmental flows along this reach (WWF 2006; Sandoval-Solis and McKinney 2009) and on a policy to provide environmental flows to the Big Bend reach.
Fig. 7 shows the increment in the sustainability ( $\Delta$ sust.) attributable to Scenario C. In the United States, two regions benefit: Amistad-Falcon and the lower Rio Grande valley. In Mexico, three regions benefit: Rio Conchos, Amistad-Falcon, and Bajo Rio Bravo subbasins. The geographic display of results allows identification of regions at risk and regions that will benefit from an alternative water management policy.

\section{Conclusions}

The extent to which water management policies are sustainable can be determined using the SI proposed in this paper. The SI identifies policies that preserve or improve the desired water management characteristics of the basin in the future. The SI makes it easier to evaluate, compare, and identify adaptive policies that improve water management when trade-offs among performance criteria occur. The comparison of the SI among different policies allows identifying (1) if a policy is working, i.e., in Scenario A, despite the efforts to improve the water supply of DR-005 by reducing its water demand, the SI shows that its water supply is still unsustainable because the maximum deficit problem has not been solved; (2) when a policy starts working, i.e., in Scenario A the policy starts working after the water demand of DR-005 has been reduced to $70 \%$; (3) by how much the policy improves the water management, i.e., in Scenario A the SI for VMc Camargo increases 33\% when the water demand of DR-005 is reduced from $100 \%$ to $90 \%$, and the savings are allocated to the environment; (4) at what point a policy becomes useful, i.e., in Scenario A the SI for VMc Camargo become steady at $60 \%$, meaning that this policy is effective up to a $40 \%$ reduction in DR-005 demand; and (5) if it affects other water users, i.e., the SI shows that Scenario B also benefits the treaty obligations. The SI promotes a holistic water management evaluation because incorporates tailor-made performance criteria in the index structure and uses different structures in the same system. The SI is versatile; it was successfully applied to water users, environmental, and system requirements.

The SG was successfully implemented to summarize the individual SI calculated for each water user, environmental, or system requirements. Similar to the SI, the SG make easier to evaluate, compare, and identify adaptive policies that improve water management for groups of water users. The SG is versatile; groups of water users can be integrated according to the type of use 
(agriculture, municipal, environment), jurisdiction (United States, Mexico) or subbasin. The comparison of the SG among different policies allows identifying which group of water users benefits and by how much, with respect to the reference scenario. By grouping water user according to their location, the SG makes it possible to identify regions that are at risk from unsustainable water management policies and regions that will benefit from an alternative water management policy. Determining weights for the SG through the annual water demand is used in this paper as an alternative method when explicit weights for water users, system requirements, and the environment are not defined.

The SI and SG have been presented to decision makers in the basin who have recognized the practicality of the index. On one hand, the SI synthesizes the performance criteria that otherwise are tedious to analyze. On the other hand, SG is more convenient to compare the performance of groups of water users and regions at a glance.

\section{Recommendations}

The SI is not intended to replace any performance criteria (e.g., reliability, resilience, vulnerability); its objective is to make easier the quantification and identification of policies that improve water management when there are trade-offs among criteria. The SI can be included as one of the water management goals when decisions are being made regarding the design, planning, and operation policies of water resource systems.

The methodology proposed in this article helps identify policies that are more sustainable than a policy used as a reference (i.e., baseline scenario) given the performance criteria considered for each water management group and the weights used in the SG. One drawback of the methodology proposed is the involvement of subjective judgment during the selection of performance criteria for the SI and weights for the SG.

In the simulation process, further research is needed to estimate and evaluate water management of the basin under different hydrologic conditions, considering the alteration of the hydrological cycle due to climate change. Also, in this research, water demands are considered fixed for the hydrologic period of analysis. Further research is needed to estimate future demands and their evaluation in the planning simulation model.

\section{Acknowledgments}

The authors would like to thank the National Council of Science and Technology of Mexico (CONACYT) for the financial support provided to the first author. Partial funding for this research was provided by the U.S. EPA, the USDA, and the Instituto Mexicano de Tecnología del Agua. Special thanks are given to the National Heritage Institute and the Stockholm Environment Institute for their support.

\section{References}

Brown, R. M., McClelland, N. I., Deininger, R. A., and O'Connor, M. F. (1972). "A water quality index - Crashing the psychological barrier." Indicators of environmental quality, Plenum, New York.

Cai, X., McKinney, D. C., and Lasdon, L. S. (2002). "A framework for sustainability analysis in water resources management and application to the Syr Darya basin." Water Resour. Res., 38(6), 1085-1098.

Collado, J. (2002). Criterios de distribución del agua en la Cuenca del Rio Bravo, Instituto Mexicano de Tecnología del Agua (IMTA), Cuernavaca, México (in Spanish).
Comisión Nacional del Agua (CONAGUA). (2004a). Ley de aguas nacionales y su reglamento, Mexico City (in Spanish).

Comisión Nacional del Agua (CONAGUA). (2004b). Registro público de derechos de agua, Mexico City (in Spanish).

Danner, C. L., McKinney, D. C., Teasley, R. L., and Sandoval-Solis, S. (2006). "Documentation and testing of the WEAP model for the Rio Grande/Bravo basin." Online Rep. 06-08, Center for Research in Water Resources, Univ. of Texas, Austin, TX.

Enriquez-Coyro, E. (1976). "El tratado entre México y los Estados Unidos de América sobre ríos internacionales." Facultad de Ciencias Políticas y Sociales, Universidad Nacional Autónoma de México, Mexico City (in Spanish).

Esty, D. C., Levy, M., Srebotnjak, T., and Sherbinin, A. (2005). 2005 environmental sustainability index: Benchmarking national environmental stewardship, Yale Center for Environmental Law and Policy, New Haven, CT.

Fanai, N., and Burn, D. H. (1997). "Reversibility as a sustainability criterion for project selection." Int. J. Sustain. Dev. World Ecol., 4(4), $259-273$.

Giorgi, F., and Mearns, L. O. (2002). "Calculation of average, uncertainty range, and reliability of regional climate changes from AOGCM simulations via the reliability ensemble averaging (REA) method." J. Clim., 15(10), 1141-1158.

Gwartney, J., Lawson, R., and Block, W. (1996). Economic freedom of the world (1975-1995), Free Market Foundation, Johannesburg, South Africa, $1-46$

Hajk kowicz, S. (2006). "Multi-attributed environmental index construction." Ecologic. Econ., 57(1), 122-139.

Hashimoto, T., Stedinger, J. R., and Loucks, D. P. (1982). "Reliability, resiliency and vulnerability criteria for water resource system performance evaluation." Water Resour. Res., 18(1), 14-20.

Hirsch, R. M. (1979). "Synthetic hydrology and water supply reliability." Water Resour. Res., 15(6), 1603-1615.

Hopkins, M. (1991). "Human development revisited: A new UNDP report." World Dev., 19(10), 1469-1473.

International Boundary and Water Commission (IBWC). (1906). Convention between the United States and Mexico. Equitable distribution of waters of the Rio Grande, El Paso, TX.

International Boundary and Water Commission (IBWC). (1944). Treaty between the United States and Mexico. Utilization of waters of the Colorado and Tijuana Rivers and of the Rio Grande, Washington, DC.

International Boundary and Water Commission (IBWC). (2003). "Volumes of water saved with the modernization and improved technology projects for the irrigation districts in the Rio Conchos basin and measures for their conveyance to the Rio Grande." Minute 309, El Paso, TX.

International Union for Conservation of Nature (IUCN). (1980). The world conservation strategy: Living resource conservation for sustainable development, International Union for Conservation of Nature, United Nations Environment Program, and World Wildlife Fund, Gland, Switzerland.

Klemes, V., Srikanthan, R., and McMahon, T. A. (1981). "Long-memory flow models in reservoir analysis: What is their practical value?" Water Resour. Res., 17(3), 737-751.

Lence, B. J., Furst, J., and Matheson, S. (1997). "Distributive fairness as a criterion for sustainability evaluative measures and application to project selection." Int. J. Sustain. Dev. World Ecol., 4(4), 245-258.

Loucks, D. P. (1997). "Quantifying trends in system sustainability.” Hydrol. Sci. J., 42(4), 513-530.

Loucks, D. P., and van Beek, E. (2005). Water resources systems planning and management, United Nations Educational, Scientific and Cultural Organization (UNESCO), Paris.

McMahon, T. A., Adeloye, A. J., and Sen-Lin, Z. (2006). "Understanding performance measures of reservoirs." J. Hydrol. (Amsterdam), 324 (2006) 359-382.

Mendoza, V. M., Villanuave, E. E., and Adem, J. (1997). "Vulnerability of basins and watersheds in Mexico to global climate change." Clim. Res., 9, 139-145.

Milbrink, G. (1983). "An improved environmental index based on the relative abundance of oligochaete species." Hydrobiologia, 102(2), $89-97$. 
Moy, W. S., Cohon, J. L., and Revelle, C. S. (1986). "A programming model for analysis of reliability, resilience and vulnerability of a water supply reservoir." Water Resour. Res., 22(4), 489.

Palmer, W. C. (1965). "Meteorological drought." Research Paper 45, Weather Bureau, U.S. Dept. of Commerce, Washington, DC, 58.

R. J. Brandes Co. (2004). "Water availability modeling for the Río Grande basin: Water availability assessment. Final report." Texas Commission on Environmental Quality, Austin, TX.

Ray, P. A., Vogel, R. M., and Watkins, D. W. (2010). "Robust optimization using a variety of performance indices." Proc., World Environmental and Water Resources Congress, ASCE, Reston, VA.

Reiquam, H. (1972). "Establishing priorities among environmental stresses." Indicators of environmental quality, Plenum, New York.

Sagar, A. D., and Najam, A. (1998). "The human development index: A critical review." Ecologic. Econ., 25(3), 249-264.

Sainz, P. (1989). "An index of social welfare." Towards a new way to measure development, Office of the South Commission, Caracas, Venezuela, 156-160.

Sandoval-Solis, S., and McKinney, D. C. (2009). "Hydrological feasibility of environmental flows in the Rio Grande/Bravo basin." Proc., World Environmental and Water Resources Congress, ASCE, Reston, VA.

Sandoval-Solis, S., McKinney, D. C., Teasley, R. L., and Patino-Gomez, C. (2011). "Groundwater banking in the Rio Grande basin." J. Water Resour. Plann. Manage., 137(1), 62-71

Secretaria de Agricultura, Ganadería, Desarrollo Rural, Pesca y Alimentación (SAGARPA). (2003). "Reglas de operación del programa de adquisición de derechos de uso del agua.” Diario Oficial de la Federación, Mexico City (in Spanish).
Simonovic, S. P. (1998). "Sustainable reservoir development and management." No. 251, International Association of Hydrological Sciences, Wallingford, UK.

Slottje, D. J. (1991). "Measuring the quality of life across countries." Rev. Econ. Stat., 73(4), 684-693.

Texas Commission on Environmental Quality (TCEQ). (2005). "Rio Grande water master program." Austin, TX.

Texas Commission on Environmental Quality (TCEQ). (2006). "Operation of the Rio Grande: Allocation and distribution of waters." Texas Administrative Code Title 30: Environmental quality, Part 1, Chapter 303, Subchapter C, Austin, TX.

Texas Commission on Environmental Quality (TCEQ). (2007). "Water availability models: Rio Grande basin." Austin, TX.

Vigerstol, K. (2002). "Drought management in Mexico's Rio Bravo basin." M.S. thesis, Univ. of Washington, Seattle.

Von Neumann, J., and Morgenstern, O. (1974). Theory of games and economic behavior, Princeton University Press, Princeton, NJ.

World Commission on Environment and Development (WCED). (1987). "Our common future: The Brundtland report." Oxford University Press, Oxford, UK.

World Health Organization (WHO). (2009). Summary and policy implications Vision 2030: The resilience of water supply and sanitation in the face of climate change, Geneva.

World Wildlife Fund (WWF). (2006). "Conclusions from the building block method specialist work session Rio Conchos." Chihuahuan Desert Program Office, Chihuahua City, Mexico.

World Wildlife Fund (WWF). (2007). World's top 10 rivers at risk, Gland, Switzerland.

Zongxue, X., Jinno, K., Kawanura, A., Takesaki, S., and Ito, K. (1998). "Performance risk analysis for Fukuoka water supply system." Water Resour. Manage., 12, 13-30.

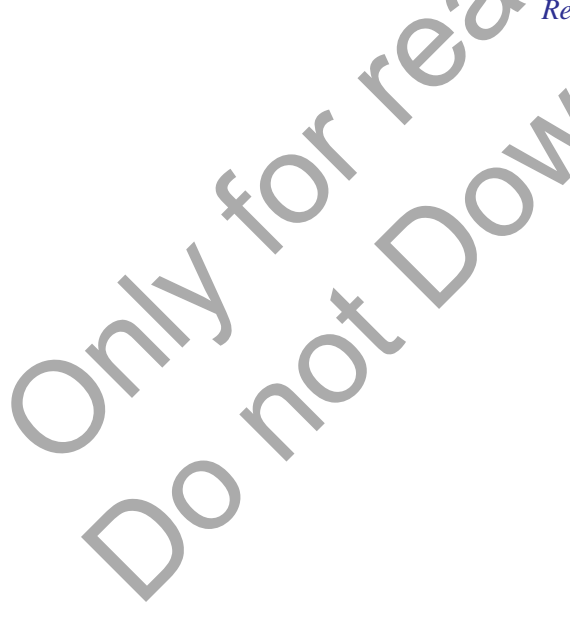

